\title{
PHAGOCYTOSIS MEASURED AS INHIBITION OF URIDINE UPTAKE: A METHOD THAT DISTINGUISHES BETWEEN SURFACE ADHERENCE AND INGESTION
}

\author{
C. LAM AND G. E. Mathison \\ Department of Microbiology, Queen Elizabeth College, \\ Campden Hill Road, London W8 7 AH
}

A CRITICAL difficulty in the quantitation of phagocytosis has been the lack of a method that distinguishes precisely between micro-organisms attached to or ingested by phagocytes. The distinction is particularly important when an investigator attempts to evaluate the capacity of phagocytes to kill ingested organisms. When the test organisms are rapidly growing bacteria, antimicrobials are often added to suppress the growth of non-phagocytosed bacteria on the questionable assumption that the conditions of the test will not allow the antimicrobial agents to penetrate the phagocytic cells (Wilkinson, 1977). There is controversy concerning the penetration or non-penetration of phagocytic cells by various antibiotics and the extent to which penetration may be concentration dependent.

Methods previously used for the evaluation of the phagocytosis of microorganisms may depend upon the evidence of stained smears revealed by light microscopy (Chang, 1969; Patterson and Youmans, 1970; Cole and Brostoff, 1975) or by phase-contrast microscopy (Swanson et al., 1974; Gibbs and Roberts, 1975). Other approaches include the recovery of cell-associated microbes after attempts to remove extracellular organisms by exposure to enzymes, antisera or antimicrobial agents (Tan, Watanakunakorn and Phair, 1971; Cole and Brostoff, 1975; Veale et al., 1976; Verhoef, Peterson and Quie, 1977). A significant attempt to improve the quantitation of the phagocytosis of yeasts by human polymorphonuclear leucocytes has been described by Yamamura, Boler and Valdimarsson (1977). The underlying principle is that uridine is incorporated by yeast cells but not by polymorphonuclear leucocytes. Yeast cells merely attached to the leucocyte surface still incorporate uridine whereas ingested yeast cells within the leucocyte do not. If a suspension of yeast cells is exposed to a pulse of tritiated uridine, the incorporation of the radioactive label can be measured. If an identical suspension is first mixed with leucocytes, there is an inhibition of incorporation related to the amount of phagocytosis, and an assessment of the fraction of the yeast cells that is truly intracellular can be made.

We report here the extension of this principle to the quantitation of bacterial phagocytosis by measurement of ${ }^{14} \mathrm{C}$-uridine instead of ${ }^{3} \mathrm{H}$-uridine incorporation.

Received 8 Feb. 1979; accepted 1 Mar. 1979.

J. MED. MICROBIOL. - VOL. I2(1979) 


\section{MATERIALS AND METHODS}

Test organism. Staphylococcus aureus strain $\mathrm{C} 18$ from our departmental culture collection was stored on Nutrient Agar (Oxoid) slopes and subcultures were made in Soya Tryptone Broth (Oxoid). Log-phase cells grown at $37^{\circ} \mathrm{C}$ were harvested by centrifugation and washed three times in warm Eagle's Minimum Essential Medium (Wellcome Laboratories) containing 10\% pooled rabbit serum and diluted to $2.5 \times 10^{6} \mathrm{c} . \mathrm{f}$.u. $/ \mathrm{ml}$.

Polymorphonuclear leucocytes (PMN) were separated from heparinised rabbit-blood by the method of Böyum (1968) which involves the sedimentation of granulocytes and erythrocytes through a Ficoll-Paque (Pharmacia Fine Chemicals) layer followed by lysis of the erythrocytes in Tris- $\mathrm{NH}_{4} \mathrm{Cl}$. The purified PMN suspension was washed three times in Eagle's minimum essential medium with $10 \%$ pooled rabbit serum and the cell count adjusted to $2.5 \times 10^{6}$ $\mathrm{PMN} / \mathrm{ml}$.

Immune serum. Antiserum against Staphylococcus aureus strain $\mathrm{C} 18$ was raised in rabbits immunised with heat-killed bacteria in complete Freund's adjuvant. The animals received $20 \times 0.1 \mathrm{ml}$ of a suspension containing $10^{6} \mathrm{bacteria} / \mathrm{ml}$ inoculated subcutaneously. The procedure was repeated at weekly intervals for 4 weeks. The agglutinating titre of the serum obtained was 640 .

Labelled uridine. $\left[2-{ }^{14} \mathrm{C}\right]$-uridine with a specific activity of $56 \mathrm{mCi} / \mathrm{mmol}$ was obtained from the Radiochemical Centre, Amersham, Bucks.

Phagocytosis assay procedure with ${ }^{14} \mathrm{C}$-uridine. Unless stated otherwise, assays were set up in duplicate in sterile siliconised screw-capped containers. The incubation mixture contained $2.5 \times 10^{6} \mathrm{PMN}$ and $2.5 \times 10^{6}$ c.f.u. of staphylococci in a final volume of $1 \mathrm{ml}$ of Eagle's minimum essential medium containing $10 \%$ pooled serum. When immune serum was used in the tests it was incorporated into the mixtures at a final dilution of 1 in 1000 , i.e., less than its agglutinating titre for the test bacterium. Control mixtures lacking bacteria or PMN were also prepared. The bottles were rotated in a horizontal position at $37^{\circ} \mathrm{C}$ on a tube-rolling machine set at approximately 1 r.p.m. (Luckham Ltd). After specified periods to allow phagocytosis to take place the mixtures were further incubated with $5 \times 10^{-3} \mu \mathrm{Ci}{ }^{14} \mathrm{C}$-uridine $/ \mathrm{ml}$ for $60 \mathrm{~min}$. The staphylococci and PMN were then recovered on a membrane filter (Sartorius, $0.45 \mu \mathrm{m}$ ), washed three times with distilled water and dried at $37^{\circ} \mathrm{C}$ for $2 \mathrm{~h}$. The radioactivity associated with the recovered cells was measured on a Beckman LS 233 liquid scintillation spectrometer with $10 \mathrm{ml}$ of $1 \%(\mathrm{w} / \mathrm{v})$ butyl PBD (2-(4'-tert-butylphenyl)-5-(4"-biphenylyl)-1,3,4-oxadiazole), in toluene, as scintillation fluid.

Phagocytosis assay based on a viable-count method. Mixtures were set up and incubated as described in the previous section. After the various periods to allow phagocytosis to occur, the samples were centrifuged at $400 \mathrm{~g}$ for $5 \mathrm{~min}$. to deposit the PMN and PMN-associated staphylococci. The pellet was resuspended in Hanks's buffered saline solution and the centrifugation and washing repeated twice to remove as many non-phagocytosed bacteria as possible. The final pellet was resuspended in distilled water to lyse the PMN and the viability of the staphylococci was determined by rapidly diluting and plating six replicate $20-\mu \mathrm{l}$ portions of decimal dilutions on the surface of dried nutrient-agar plates.

\section{RESULTS}

\section{${ }^{14} \mathrm{C}$-uridine incorporation by Staphylococcus aureus}

The incorporation of ${ }^{14} \mathrm{C}$-uridine can be exploited to count bacteria only when a measurable degree of incorporation is achieved within a period of incubation that does not permit multiplication of the bacteria and does not result either in exchange of the label with unlabelled compounds during subsequent manipulations or metabolic conversion of the label into labile or gaseous substances such as $\mathrm{CO}_{2}$. Staphylococcus aureus strain $\mathrm{C} 18$ incorpor- 


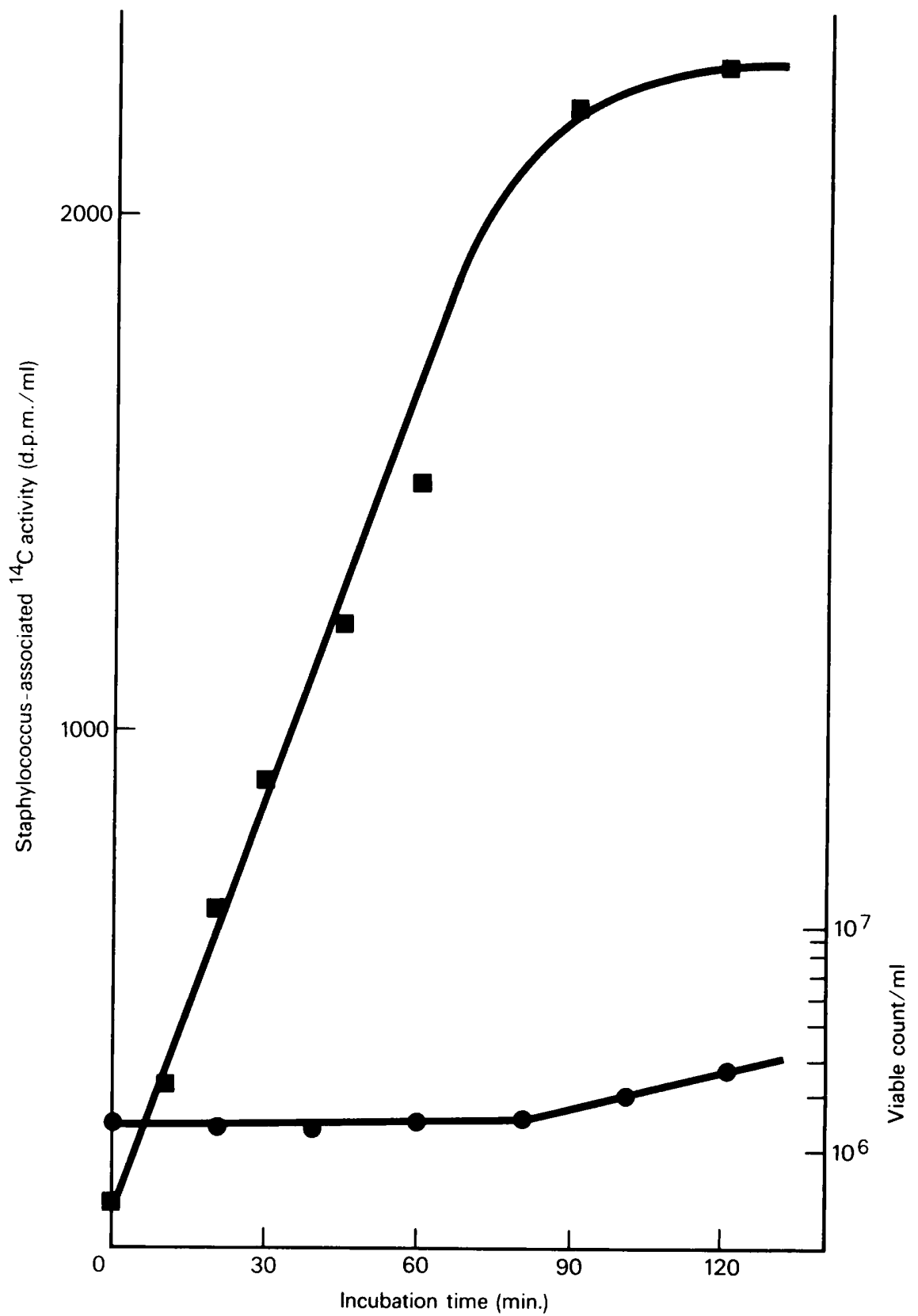

FIG. 1.-Incorporation of ${ }^{14} \mathrm{C}$-uridine by staphylococci $2 \times 10^{6} / \mathrm{ml}$ in tissue-culture medium, in conditions similar to those of the phagocytosis experiments. Samples were removed at given times and the radioactivity associated with the harvested bacteria measured (-_- the plot of the viable count of the bacteria during the labelling period is shown thus $\bullet$; d.p.m $=$ disintegrations per min. 
ated ${ }^{14} \mathrm{C}$-uridine linearly with time of incubation for the first $60-70 \mathrm{~min}$.; thereafter, saturation kinetics were observed. The number of viable staphylococci remained more or less constant during incubation for up to $80 \mathrm{~min}$., but then started to increase. Fig. 1 shows the results of a typical incorporationkinetics study with staphylococci. A 60-min. labelling period is suitable under the conditions used and avoids the complications of bacterial growth and loss of label due to metabolic activity. It was also observed (results not shown) that after the bacteria were labelled the radioactivity was not readily lost when the bacteria were diluted in fresh medium.

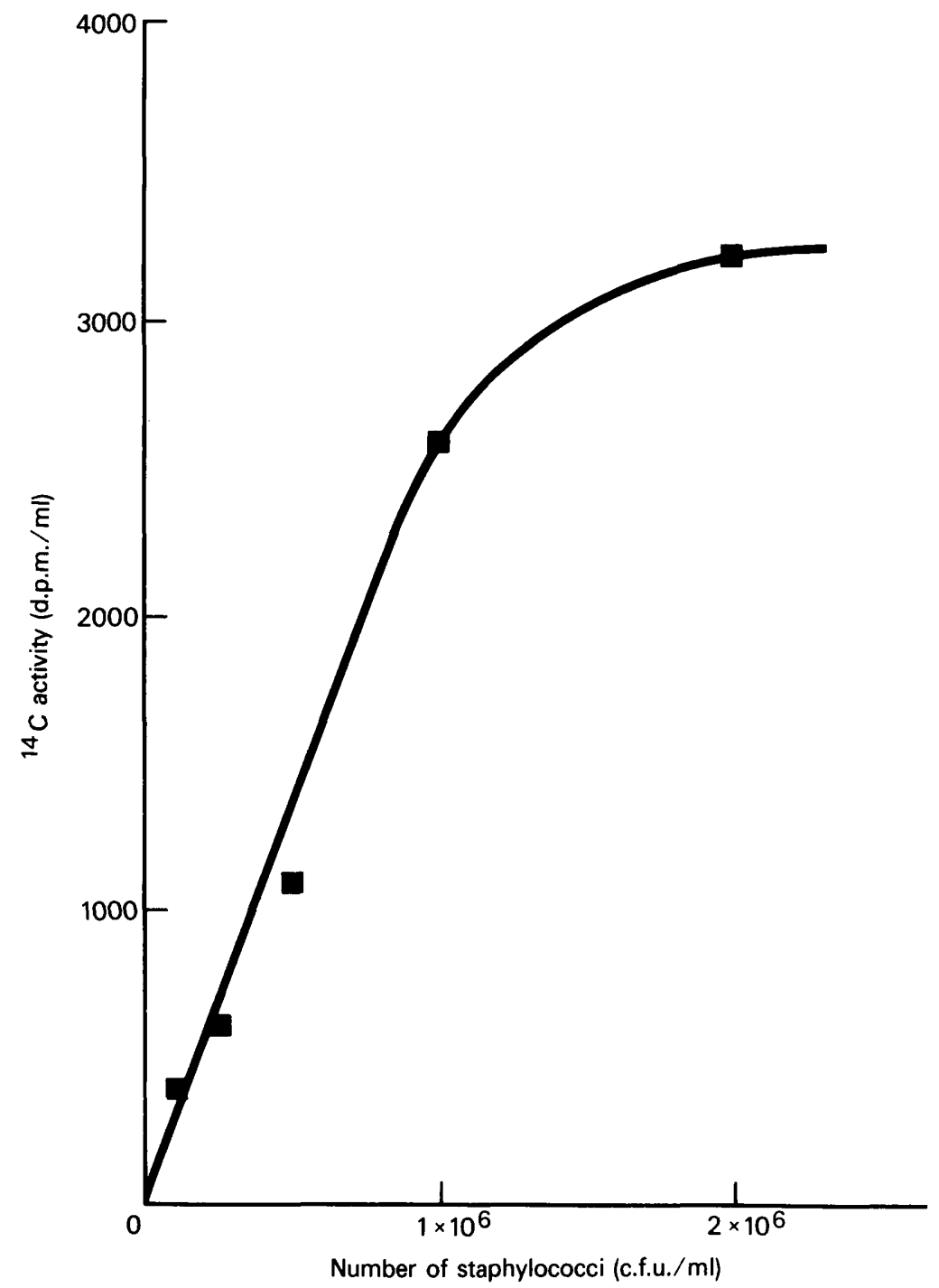

FIG. 2.-Dependence of incorporation of ${ }^{14} \mathrm{C}$-uridine on bacterial density. Various numbers of staphylococci were suspended in conditions similar to those described for phagocytosis experiments and labelled for $60 \mathrm{~min}$. 


\section{Dependence of incorporation upon bacterial concentration}

The amount of radioactivity incorporated was linearly related to the concentration of staphylococci up to about $2 \times 10^{6} \mathrm{c}$.f.u. $/ \mathrm{ml}$ during a $60-\mathrm{min}$. incubation period (fig. 2). An increase above this concentration of bacteria did not result in a proportional increase in the amount of radiolabel incorporated.

\section{Incorporation of ${ }^{14} \mathrm{C}$-uridine by the $P M N$}

For the method to be of practical value, the amount of the radioactive label incorporated by the PMN must be insignificantly small compared with that incorporated by the staphylococci. Incorporation of the label by the leucocytes ranged between the acceptably low levels of $0.2 \%$ at a PMN concentration of $5 \times 10^{5} / \mathrm{ml}$ to $3 \%$ at $2 \times 10^{7} / \mathrm{ml}$ (table I). Thus the selective incorporation of ${ }^{14} \mathrm{C}$-uridine can be exploited to estimate the number of extracellular and intracellular staphylococci in this system.

TABLE I

Incorporation of ${ }^{14} \mathrm{C}$-uridine by rabbit polymorphonuclear leucocytes (PMN)

\begin{tabular}{c|c}
\hline $\begin{array}{c}\text { PMN count } \\
\text { per ml }\end{array}$ & $\begin{array}{c}\text { Percentage } \\
\text { incorporation }\end{array}$ \\
\hline $2 \times 10^{5}$ & 0.2 \\
$2 \times 10^{6}$ & 1.5 \\
$2 \times 10^{7}$ & 3.0 \\
\hline
\end{tabular}

Serum requirements for opsonisation of Staphylococcus aureus for phagocytosis by $P M N$ measured as 1) inhibition of ${ }^{14} \mathrm{C}$-uridine incorporation and 2) viable staphylococci associated with PMN

The requirement for serum is clearly demonstrated by the results shown in table II. Inhibition of incorporation of label was $80 \%$ and $83 \%$ when the phagocytosis mixture had been incubated for $30 \mathrm{~min}$. and $60 \mathrm{~min}$. respectively. Fig. 3 compares the kinetics of phagocytosis as assessed by the inhibition of uridine incorporation and by the conventional method of counting the bacteria

\section{TABLE II}

Serum requirements for opsonisation of Staphylococcus aureus strain C18 by rabbit polymorphonuclear leucocytes (PMN)

\begin{tabular}{c|cc}
\hline \multirow{2}{*}{$\begin{array}{l}\text { Incubation mixture } \\
\text { PMN + Staphylococcus aureus }\end{array}$} & $\begin{array}{c}\text { Percentage inhibition of } \\
\text { uridine incorporation after }\end{array}$ \\
\cline { 2 - 3 } $\begin{array}{c}\text { PMN + Staphylococcus aureus } \\
\text { + pooled rabbit serum }\end{array}$ & $80 \cdot 0$ & $60 \mathrm{~min}$. \\
\hline
\end{tabular}




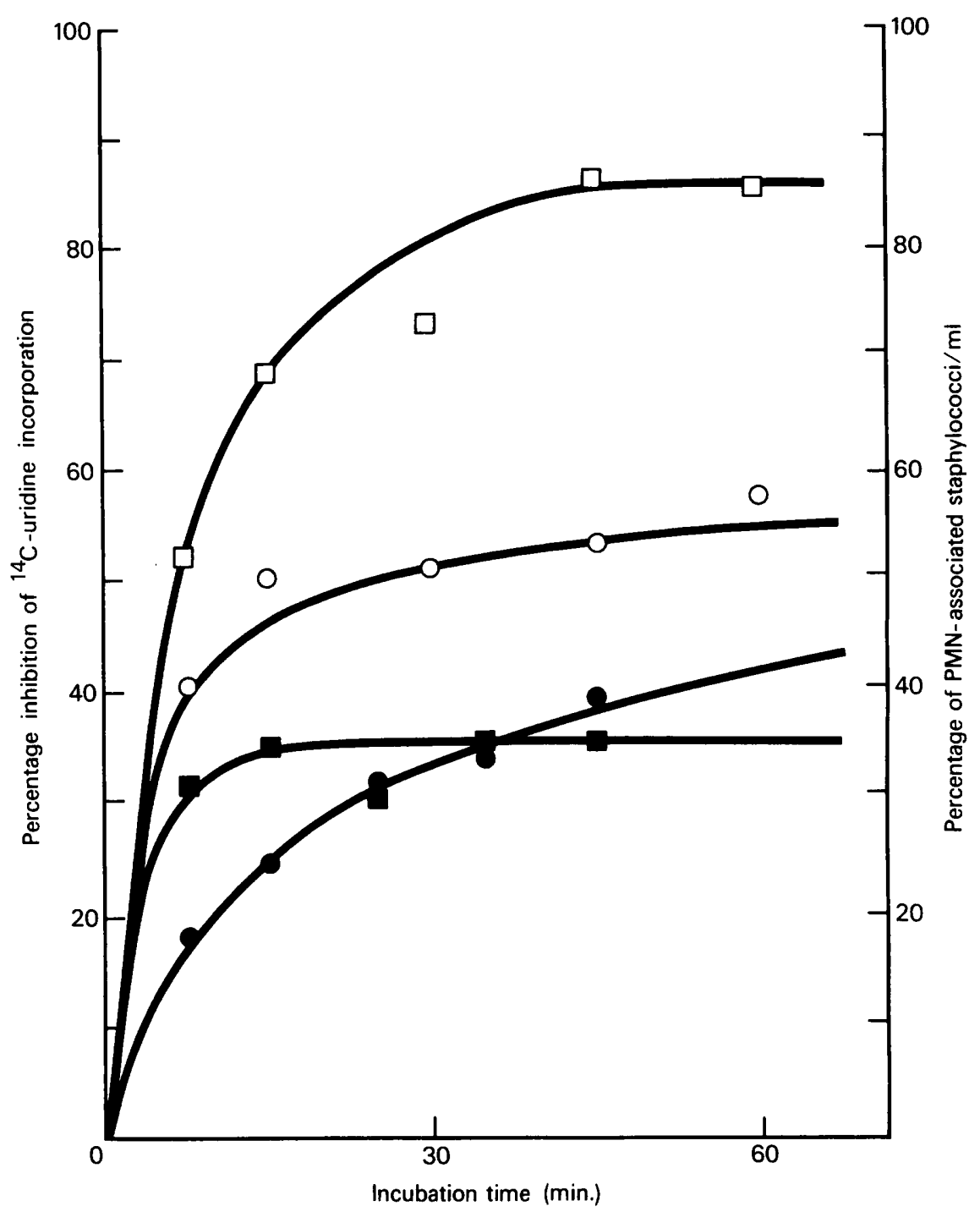

FIG. 3.-Kinetics of phagocytosis of Staphylococcus aureus by rabbit polymorphonuclear leucocytes (PMN) assessed by (1) the inhibition of ${ }^{14} \mathrm{C}$-uridine with non-immune $(\bullet-\bullet)$ and immune $\left(\square_{-}^{-}-\mathrm{a}\right)$ serum as opsonin, and (2) the conventional viable-count method (non-immune serum - ; immune serum $\stackrel{0}{0}$ ).

associated with PMN after washing. When pooled normal rabbit serum was used as the opsonin the agreement between the two methods was very close. However, in the presence of the specific antiserum the extent of ingestion as measured by the viable count was significantly lower than that measured by the incorporation method.

\section{DisCUSSION}

When phagocytosis is being measured, it is essential to distinguish between 
microbes adsorbed on to surfaces of phagocytes or trapped in leucocyte clumps and microbes that are actually ingested. Studies of phagocytosis of radioactively labelled bacteria (Michell et al, 1969; Verhoef, Peterson and Quie, 1977; Jones and Buchanan, 1978), and studies in which the microbial target and the phagocytic cells were labelled simultaneously (Jones and Buchanan, 1978) have shown that these approaches do not solve the problem. Our results show unequivocally that inhibition of radioactively labelled uridine incorporation, first used by Yamamura et al. (1977) for estimating the number of yeast cells ingested by human PMN, can be extended to measure the number of staphylococci ingested by rabbit PMN. The technique can probably be applied to phagocytic studies with other micro-organisms and other types of phagocytic cell provided that the test organism incorporates labelled uridine and retains the label and that the phagocytic cells incorporate insignificant amounts of label and can exclude extracellular label from intracellular organisms.

A clear distinction between surface binding and ingestion of bacteria is essential in comparative studies of different types of phagocytic cells or of the same types in different states of immunological activity. Accurate enumerations of extracellular bacteria are also required when the effects of antimicrobial agents on intracellular microbes are studied. It is important to quantitate accurately the killing of bacteria within phagolysosomes by the antimicrobial systems of the phagocytes and to distinguish this component from the bactericidal effect of an antimicrobial agent added to the medium to suppress extracellular bacterial growth. Our presently available procedures for these studies are very inadequate.

The method we describe offers many advantages and may also be used to assay the opsonising capacity of sera (Yamamura and Valdimarsson, 1978). Most of the tests for opsonin activity still depend upon counting ingested particles by light microscopy; even with the meticulous application of electron microscopy the difficulty of distinguishing between adherent and ingested particles remains.

However, our results indicate some limitations of the technique, at least as applied to studies of staphylococci. Because the relationship between bacterial concentration and the amount of label incorporated becomes non-linear above a bacterial count of $2 \times 10^{6} \mathrm{staphylococci} / \mathrm{ml}$, studies of circumstances in which there are high ratios of bacteria to phagocytes require a reduction of the phagocyte concentration rather than an increase in the bacterial concentration. Problems will arise if ratios of more than 20:1 are to be studied.

The experiments in which pooled normal serum was used as opsonin showed good agreement between the ${ }^{14} \mathrm{C}$-uridine method and the conventional viable-count procedure. However, when a specific immune serum was used as opsonin the uridine method recorded a significantly higher proportion of intracellular bacteria. This presumably reflects a measure of intraleucocytic killing during the period occupied in the conventional method by the removal of extracellular bacteria by centrifugation and washing. If that assumption is correct, it may be suggested that such viable-count procedures are likely to underestimate the extent of phagocytosis in the presence of powerful opsonins. 


\section{SUMMARY}

Polymorphonuclear leucocytes selectively inhibited the incorporation of ${ }^{14} \mathrm{C}$-uridine by intracellular staphylococci. Within specified limits, the amount of radiolabel incorporated by extracellular staphylococci was related to bacterial concentration. The incorporation of labelled uridine can thus be exploited to assay the extent to which association between staphylococci and polymorphonuclear leucocytes reflects surface adherence as opposed to ingestion. A comparison of the new method with a conventional viable-count determination of leucocyte-associated bacteria shows it to be comparable in efficiency when non-immune serum is used as opsonin and superior when specific opsonin is used.

We wish to thank Dr H. Valdimarsson of the Department of Immunology, St Mary's Hospital Medical School for providing facilities for one of us (CL) to acquire the basic methodology and Dr C. F. Thurston of the Department of Microbiology, Queen Elizabeth College, for advice on isotope techniques. CL is indebted to the Science Research Council for a support grant and GEM to the University of London Central Research Fund for a grant for the purchase of equipment.

\section{REFERENCES}

Böyum, A. (1968). Separation of leucocytes from blood and bone marrow. Scand. J. clin. Invest., 21, suppl. 97.

ChanG, Y. T. (1969). Suppressive activity of streptomycin on the growth of Mycobacterium leprimurium in macrophage cultures. Appl. Microbiol., 17, 750.

Cole, P. AND BRostofF, J. (1975). Intracellular killing of Listeria monocytogenes by activated macrophages (Mackaness system) is due to antibiotic. Nature (Lond.), 256, 515.

GIBBS, D. L. AND ROBERTs, R. B. (1975). The interaction in vitro between human polymorphonuclear leukocytes and Neisseria gonorrhoeae cultivated in the chick embryo. J. exp. Med., 141, 155.

JoNES, R. B. AND BuChANAN, T. M. (1978). Quantitative measurement of phagocytosis of Neisseria gonorrhoeae by mouse peritoneal macrophages. Infect. Immun., 20, 732.

Michell, R. H., Pancake, S. J., Noseworthy, J. AND Karnovsky, M. L. (1969). Measurement of rates of phagocytosis. The use of cellular monolayers. J. cell. Biol., 40, 216.

Patterson, R.J. AND Youmans, G. P. (1970). Multiplication of Mycobacterium tuberculosis within normal and "immune" mouse macrophages cultivated with and without streptomycin. Infect. Immun., 1, 30.

Swanson, J., Sparks, E., Zeligs, B., Siam, M. A. and Parrott, C. (1974). Studies on gonococcus infection. $\mathrm{V}$. Observations on in vitro interactions on gonococci and human neutrophils. Infect. Immun., 10, 633.

Tan, J. S., Watanakunakorn, C. and Phair, J. P. (1971). A modified assay of neutrophil function: use of lysostaphin to differentiate defective phagocytosis from impaired intracellular killing. J. lab. clin. Med., 78, 316.

Veale, D. R., Finch, H., Smith, H. AND Witt, K. (1976). Penetration of penicillin into human phagocytes containing Neisseria gonorrhoeae: Intracellular survival and growth at optimum concentrations of antibiotic. J. gen. Microbiol., 95, 353.

Verhoeff, J., Peterson, P. K. AND Quie, P. G. (1977). Kinetics of Staphylococcal opsonization, attachment, ingestion and killing by human polymorphonuclear leukocytes: a quantitative assay using $\left[{ }^{3} \mathrm{H}\right]$ thymidine labelled bacteria. J. immun. Meth., 14, 303.

Wilkinson, P. C. (1977). Neutrophil leucocytes function tests. In Techniques in clinical immunology, edited by R. A. Thompson, Oxford. 
Yamamura, M., Boler, J. And Valdimarsson, H. (1977). Phagocytosis measured as inhibition of uridine uptake by Candida albicans. J. immunol. Meth., 14, 19.

Yamamura, M. AND Valdimarsson, H. (1978). A new semiquantitative radiometric opsonin assay. Selective measurement of opsonizing capacity of the alternative pathway. Immunology, 34, 689. 